\title{
Attribution and authority \\ in a medieval Irish medical compendium
}

\author{
DEBORAH HAYDEN \\ (Maynooth University)
}

\begin{abstract}
This contribution will examine some aspects of an unpublished Irish medical compendium that consists mainly of herbal prescriptions for various ailments, broadly arranged in the a capite ad calcem order typical of medical treatises from both the early and later medieval periods. The collection in question is remarkable for the fact that it includes several recipes cast in verse form, as well as a number of charms, the latter of which have received the bulk of the very limited scholarly attention that has thus far been devoted to the text. An equally noteworthy aspect of this compendium is that it contains a relative paucity of references to the standard medical authorities of the university curriculum, a feature that sets it apart from many other medieval Irish translations of, or commentaries on, Latin medical texts. Particularly striking is the fact that, of the comparatively small number of references to medical authorities that do occur in the compendium, the majority invoke the Irish healer Dían Cécht and other figures of the mythological race known as the Túatha Dé Danann, whose activities are well attested in a range of other medieval Irish textual sources. The following discussion aims to shed light not only on the nature of this compendium as a whole but also on that of vernacular Irish medical writing more widely, by examining the use and context of authoritative citations within the work.
\end{abstract}

\section{The citation of authorities in medieval medicine}

A number of early, though still influential, studies of the extant Irish vernacular medical texts presented a somewhat dismissive view of this corpus as being a largely derivative and scholastically oriented product of the academic medical tradition that flourished from the eleventh century onwards in continental centres of learning such as Salerno, Montpellier, Bologna and Paris. The scientific curriculum of these emerging universities was bolstered by the recovery and translation of many Greek texts through Arabic sources, a circumstance that ultimately gave rise to Standish O'Grady's rather sweeping characterisation of the 
hereditary physicians of medieval Ireland and Scotland as 'staunch Arabians'. In a similar vein, D. A. Binchy prefaced his edition of Bretha Déin Chécht, a legal tract on injuries that forms part of the seventh-century collection of Old Irish legal material known as the Senchas Már, ${ }^{2}$ with the claim that

... the extant medical manuscripts of the fourteenth and following centuries simply reproduce in an Irish dress the second-hand Aristotelianism and the exotic remedies of Salerno, Bologna, Padua and Montpellier. Except for [Bretha Crólige, an Old-Irish law-tract on sick-maintenance] and [Bretha Déin Chécht], which were copied perhaps for their legal rather than their medical content, we do not possess a single record of pre-Arabic medicine, whether indigenous or borrowed. We have nothing like the Anglo-Saxon Leechdoms to throw light on the theory and practice of the earlier medicine, nothing beyond a few fragmentary incantations ... in one of which, incidentally, Dian Cécht is mentioned by name. ${ }^{3}$

Francis Shaw offered an equally critical assessment of the surviving evidence for medical writing in medieval Ireland, suggesting that the extant corpus of texts reveals little about medical practice at a local level:

The Irish doctor really takes his bow for the first time in the fourteenth century, and for the first time holds the stage. Unfortunately the metaphor, as we shall see, is too near to reality, for we only see him, dressed in borrowed apparel, and speaking words which are not his own ... although he writes in Irish, the learning which he cultivates, the treatment which he suggests, the cures and the diet which he prescribes are all borrowed. ${ }^{4}$

Shaw's studies of the Irish medical manuscripts highlighted the extent to which many of them contained 'a strong philosophical admixture' and bore the distinct hallmarks of scholasticism. ${ }^{5}$ This method of critical thought, cultivated

\footnotetext{
${ }^{1}$ Standish O'Grady, Catalogue of Irish manuscripts in the [British Library, formerly the] British Museum, volume 1 (London, 1926; repr. Dublin, 1992), 175.

${ }^{2}$ The most recent assessment of the composition of the Senchas Már text is that by Liam Breatnach, The Early Irish law text Senchas Már and the question of its date, E. C. Quiggin Memorial Lectures 13 (Cambridge, 2011). Breatnach argues (42) that the text, which comprises 47 constituent tracts on various aspects of legal learning, 'was conceived of and transmitted as a unitary whole' written in Armagh between roughly 660 and 680 .

${ }^{3}$ D. A. Binchy (ed.), 'Bretha Déin Chécht', Ériu 20 (1966), 5. On the citation of Dían Cécht in one of the early Irish St Gall incantations, see further below, 39-40.

${ }^{4}$ Francis Shaw, 'Irish medical men and philosophers', in Brian Ó Cuív (ed.), Seven centuries of Irish learning, 1000-1700 (Dublin, 1961), 75-86, at 78.

${ }^{5}$ Shaw, 'Irish medical men', 79; see also his 'Medieval medico-philosophical treatises in the Irish
} 
enthusiastically in the late medieval university setting, is often associated with features such as an emphasis on theory, an interest in Aristotelian natural philosophy, the use of dialectical reasoning and a particular concern for presenting and commenting on contradictory views of various cited authorities. ${ }^{6}$ As Cornelius O'Boyle has argued in his study of medical teaching at the University of Paris during the thirteenth and fourteenth centuries, the highly discursive approach to medical learning embodied by scholasticism tended to convey a conception of the discipline as one defined 'not in terms of a knowledge of particular drugs or practical techniques, but in terms of a knowledge of books. To know medicine was to know its authoritative sources.' ${ }^{7}$ The inheritance of Irish physicians from the classical learning of the nascent universities, and their familiarity with the core authors of the Renaissance medical curriculum, can be clearly seen in the Irish translation of John of Gaddesden's Rosa Anglica, completed by the mid-fifteenth century and one of the few substantial Irish medical texts to have yet been published in a modern scholarly edition. Within this work, a total of twenty-four different authorities whose works were well known in academic circles after the mid-eleventh century, such as Avicenna, Galen and Constantine the African, are cited explicitly and repeatedly, as is illustrated by a section of the text dealing with ways to restore energy to a patient:

Coimlintur in 4 ni mar adubrumar le biadhuibh sodilegtha, lenab urusa impogh a naicnid (?) na spirut, \& trit sin adeir Auicenna curub maith uisgi na feola ann so, oir impoigh co h-urusa a naduir na spirut. Tuic do reir Auicenna co méduidter in brig on fín, 7 o biadhuibh seime, 7 o balad maith, 7 o gairdechus, 7 o soinind, 7 sechnad módurracht[a], 7 feirge, 7 o thathigi neitid ngradach, 7 o coimnuighi maille dainibh disle, 7 trit sin adeir Consin, do reir ughdurais Galen, co cuirind comradh itir daine gradacha, 7 egnuidhi in saothur ona dainibh, 7 ona ballaibh inmedhonacha.

The fourth thing mentioned is accomplished by digestible foods, which easily turn to the nature of spirit; and therefore Avicenna says, water of meat is good here, as it turns easily to the nature of spirit. And know, according to Avicenna, that the force is increased by wine, and subtle foods, and by sweet odour, by joy and tranquillity, and by avoiding

\footnotetext{
language', in John Ryan (ed.), Féil-sgríbhinn Eóin Mhic Néill. Essays and studies presented to Professor Eoin Mac Neill (Dublin, 1940; repr. 1995), 144-57.

${ }^{6}$ On the scholastic method in medieval European medical education, see Nancy Siraisi, Medieval and early Renaissance medicine: an introduction to knowledge and practice (Chicago and London, 1990), 73-76, as well as Luke Demaitre, 'Scholasticism in compendia of practical medicine, 1250-1450', Manuscripta 20:1 (1976), 81-95.

${ }^{7}$ Cornelius O'Boyle, The art of medicine: medical teaching at the University of Paris, 1250-1400, Education and Society in the Middle Ages and Renaissance 9 (Leiden, 1998), 265-66.
} 
depression and anger, and by rejoicing in pleasant things, and by remaining with friends. Therefore Constantine says, on the authority of Galen, that conversation between lovers and sages removes trouble from people, and from the interior members. ${ }^{8}$

That Irish physicians and translators were well acquainted with a much wider range of Latin authors than those called upon in the above example, and were eager to assign credit where credit was due, is equally evident from just a fleeting glance at O'Grady's list of over thirty authorities cited in the Irish medical manuscripts at the British Library. ${ }^{9}$

Yet while the influence of well-known classical and Renaissance medical authorities on the surviving corpus of Irish medical writing is manifest from such authorial attributions as these, more recent scholarship has nonetheless sought to establish a more nuanced picture of this corpus than that painted by scholars such as O'Grady, Binchy and Shaw. For example, Aoibheann Nic Dhonnchadha has argued that, contrary to what Shaw suggested regarding the provenance of medical cures prescribed in the Irish texts, it was in fact common practice for Irish physicians to recommend numerous ingredients derived from plants that would have been available locally, or to substitute non-native substances for indigenous ones. ${ }^{10}$ Close analysis of specific texts has shown, moreover, that even late medieval translations with easily recognisable Latin sources are often not simply slavish renderings from one language to another, but in fact, the products of extensive and creative adaptation on the part of their authors, who would frequently alter or abridge material for the practical purposes of their day-to-day work. ${ }^{11}$ In a study of the Latinity of Irish doctors during the early modern period, Jason Harris has likewise argued for the existence of a 'complex, variegated medical community' that was 'not out of step with the European-wide trend towards the cultivation of vernacular medical discourse

\footnotetext{
${ }^{8}$ Winifred Wulff (ed. and trans.), Rosa anglica seu rosa medicince Johannis Anglici: an early modern Irish translation of a section of the mediaeval medical text-book of John of Gaddesden, Irish Texts Society 25 (London, 1929), 152-53. Wulff provides a list of doctors whose works are quoted in the text on pp. 416-19 of her edition. For the most recent discussion of this work and its wider context, see Liam P. Ó Murchú (ed.), Rosa Anglica: reassessments, Irish Texts Society Subsidiary Series 28 (London, 2016).

${ }^{9}$ O’Grady, Catalogue, 173-74.

${ }^{10}$ Aoibheann Nic Dhonnchadha, 'Medical writing in Irish', Irish Journal of Medical Science 169:3 (July-September 2000), 217-20, at 220 (repr. from J. B. Lyons (ed.), 2000 Years of Irish Medicine (Dublin, 1999), 21-26).

${ }^{11}$ On this, see for example the comments by Aoibheann Nic Dhonnchadha, 'The medical school of Aghmacart, Queen's County', Ossory, Laois and Leinster 2 (2006), 11-43, at 18-19; ead., 'Eagarthóir, téacs agus lámhscríbhinní: Winifred Wulff agus an Rosa Anglica', in Ruairí Ó hUiginn (ed.), Oidhreacht na lámhscribhinní, Léachtai Cholm Cille 34 (Maynooth, 2004), 105-47; ead., 'The Irish Rosa Anglica: manuscripts and structure', in Ó Murchú, Rosa Anglica: reassessments, 114-97, at 165-74; and Nessa Ní Shéaghdha, 'Translations and adaptations into Irish', Celtica 16 (1984), $107-24$, at 113 .
} 
in communities of practice that fed off but were independent of the world of universities'. ${ }^{12}$

It is important to bear in mind, moreover, that the features outlined above as being most readily associated with late medieval scholastic methods, such as an emphasis on the importance of explicitly citing authoritative sources, are decidedly more pronounced in certain subgenres of medieval medical writing than others - notably commentaries, Quaestiones or treatises on medical theory. These categories of text can be contrasted with the numerous Latin compendia of practical medicine composed between the eleventh and fifteenth centuries, which aimed at summarising the physician's entire procedure for each particular disease, frequently in head-to-toe order. ${ }^{13}$ As Luke Demaitre has pointed out, the presentation and selection of sources vary widely in texts belonging to this latter group: for example, only eight scientific authors are mentioned by name in Gulielmus de Saliceto's Summa conservationis et curationis (1275), while eighteen are noted in Bernard of Gordon's Practica seu Lilium medicine (1303), compared to forty-six in John of Gaddesden's Rosa Anglica practica medicine (1314). ${ }^{14}$ Demaitre further notes that 'the frequency of explicit references ran from a low of one identified author in about every 400 words in Gordon's Lilium to a high of one in about sixty words in Saliceto's Summa'. Such variation is significant for the present study, since these empirically oriented medical compendia-which aimed at 'practical convenience or utilitas, rather than inquiry and scientia $a^{15}$ — in many respects bear comparison, at least on the level of content and overarching structure, to the Irish vernacular medical compendium considered here. ${ }^{16}$

It is likewise worth noting, however, that the Irish compendium in question also shows similarities, in terms of its structural arrangement, general lack of interest in theory and sparing use of authoritative attributions, with practices evidenced in much medical writing from the earlier medieval period. The characteristics of the latter have been cogently articulated by Faith Wallis:

In early medieval medical manuscripts, reverence for ancient authority coincides with extraordinary indifference to textual authenticity. Almost all the texts actually ascribed to Galen, for example, are pseudepigrapha; on the other hand, virtually all the genuine Galenic texts appear as

\footnotetext{
${ }^{12}$ Jason Harris, 'Latin learning and Irish physicians, c.1350-c.1610', in Ó Murchú, Rosa Anglica: reassessments, $1-25$, at 25 .

${ }^{13}$ For a detailed account of several such manuals, see Luke Demaitre, Medieval medicine: the art of healing, from head to toe (Santa Barbara, CA, 2013).

${ }^{14}$ Demaitre, 'Scholasticism', 87.

${ }^{15}$ Ibid., 85 .

${ }^{16}$ For a preliminary discussion of the verse material in the compendium, see Deborah Hayden, 'Three versified medical recipes invoking Dían Cécht', in Anders Ahlqvist and Pamela O'Neill (eds), Fír fesso: A Festschrift for Neil McLeod, Sydney Series in Celtic Studies 17 (Sydney, 2018), 107-23. On the charms included in the text, see further below, n. 38.
} 
fragments in anthologies, stripped of the author's name. This process of decanonizing ancient texts took a number of forms. The parent text might be dismembered into excerpts presented in isolation, or else creatively reassembled into new composite texts. Very frequently, the text was 'de-authorized' in the excerpting process.... Conversely, anonymous texts might be ascribed to an ancient authority, either by a sort of scholarly reflex (if it is medicine, it must be Galen or Hippocrates) or because the text in question bore a generic resemblance to a genuine ancient text by that author. ... It is here, indeed, that we can best observe what truly interested early medieval medical readers, for the more interested they were in a subject, the more they tinkered with its texts. Pharmacology, materia medica and recipe literature are by far the best represented subject areas in the manuscripts. Consequently, probably the most disturbed textual traditions are found in herbal pharmacology. ${ }^{17}$

A case in point is the corpus of English medical texts compiled between the late ninth and twelfth centuries, which have long been held to offer an unparalleled example of early medieval medical lore written in a northern European vernacular. ${ }^{18}$ Banham has characterised the use of authoritative attributions in these works as follows:

... they consist almost entirely of recipes, mostly in the standard terse recipe style: for $\mathrm{x}$, take $\mathrm{y}$, and do $\mathrm{z}$ with it—probatum est. Most of their authors, or compilers, do not concern themselves with theory. But the Old English medical texts do not represent a naïve native medicine entirely unrelated to the sophisticated sub-classical discipline of the continental West. Many, probably a majority, of the recipes in them are translated from the Latin, and derive ultimately from classical sources. This classical background is hidden from the reader, however, not only by the change of language, but by the fact that ... authorities are almost never cited. Only when Latin medical texts arrive in England around the middle of the eleventh century do we start to find the standard classical authorities (Hippocrates, Galen) we might expect. Whether our texts, with their apparent lack of intellectual connectedness, are practical, in the sense of being directly related to medical activity in early medieval England, is hard to determine in the almost complete absence of evidence for Anglo-Saxon practice outside the texts. ${ }^{19}$

\footnotetext{
${ }^{17}$ Faith Wallis, 'The experience of the book: manuscripts, texts, and the role of epistemology in early medieval medicine', in Don Bates (ed.), Knowledge and the scholarly medical traditions (Cambridge, 1995), 101-26, at 107-9.

${ }^{18}$ For this claim, see, for example, M. L. Cameron, Anglo-Saxon medicine, Cambridge Studies in Anglo-Saxon England 7 (Cambridge, 1993), 1.

${ }^{19}$ Debby Banham, 'Dun, Oxa and Pliny the great physician: attribution and authority in Old English medical texts', Social History of Medicine 24:1 (2011), 57-73, at 58.
} 
Banham shows that, in the case of texts such as the Old English Herbarium and the Peri Didaxeon - both of which are clearly translations from known Latin worksattributions of individual recipes to particular authorities are rare. However, the texts do retain the overall attributions of the Latin originals, in addition to introductory paragraphs or manuscript frontispieces which suggest that the material in question was in some way associated with mythological figures such as Aesculapius, the Greek god of medicine. ${ }^{20}$ Of the few authorities cited for the medical collections compiled in England, such as 'Bald's Leechbook'-which, like the Irish medical compendium to be examined here, consists in large part of herbal recipes arranged in head-to-toe order-some cures are attributed to individuals who are unknown elsewhere, such as the mysterious 'Dun' and 'Oxa'. Banham suggested that these figures may have been Anglo-Saxon medical practitioners and noted that what is interesting about the inclusion of their names in an otherwise largely anonymous text is that the compiler of the work felt no need to provide any further information about them: the reader was presumably expected to know who they were, perhaps indicating that they would have belonged to the same community of medical practitioners. ${ }^{21}$ She further argued that the attitudes to authority revealed in the Old English vernacular medical works as a whole pointed to 'a rather self-sufficient medical community in England, with limited historical awareness or contact with wider developments, at least until new Latin medical texts came in from the continent in the eleventh century, ${ }^{22}$

In the realm of vernacular medical writing, comparanda for our Irish compendium can also be found in Anglo-Norman and Welsh medical texts compiled around the thirteenth century, which likewise consist in large part of practically oriented recipe collections for various ailments. For example, I have considered elsewhere the similarities between the medical poems preserved in the Irish compendium examined here and a collection of French versified recipes known as the Physique rimée, which has been described by Tony Hunt, in his study of 'popular' medicine in thirteenth-century England, as being 'designed to introduce those who have no Latin ... to the useful properties of herbs and plants the names of which may already be familiar to them, ${ }^{23}$ The surviving Welsh medical recipe collections were first compiled at a similar period, but may draw at least in part on material of a much earlier date. ${ }^{24}$ Although colophons attached to some versions of these collections

\footnotetext{
${ }^{20}$ Banham, 'Dun, Oxa and Pliny', 62.

${ }^{21}$ Ibid., 63-64 and 67.

${ }^{22}$ Ibid., 57.

${ }^{23}$ Tony Hunt, Popular medicine in thirteenth-century England (Cambridge, 1990), 144; see also the discussion in Hayden, 'Three versified medical recipes', 116-17.

${ }^{24}$ For editions of the Welsh medical texts, see John Williams Ab Ithel (ed.) and John Pughe (trans.), The physicians of Myddvai. Meddygon Myddfai (Llandovery, 1861); Pol Diverres (ed. and trans.), Le plus ançien texte des Meddygon Myddveu (Paris, 1913); and Ida B. Jones (ed. and trans.), 'Hafod 16, a mediaeval Welsh medical treatise', Études celtiques 7:1 (1955-56), 46-75; continued in 7:2 (1955-56), 270-339; 8:1 (1958-59), 66-97; and 8:2 (1958-59), 346-93.
} 
cite the authority of a hereditary family of physicians in Myddfai, Carmarthenshire, individual recipes within the collections contain virtually no references to particular authorities, classical or otherwise. In a survey of this material, Owen remarked that many of these recipes, which she saw as reflecting both post-eleventh-century Arabic medicine and classical medical doctrine known in Europe at an earlier period, are 'relatively simple', showing 'patterns of expression that are found in the technical prose of a more native kind and connected with the activities of the other professional learned classes of medieval Wales, namely the prose of the bards and lawyers'. ${ }^{25}$

In the same study of the Welsh medical material, however, Owen echoed the opinions of earlier scholars regarding the nature of the extant Irish medical manuscripts by claiming that 'all the surviving Gaelic medical tracts are the products of the scholasticism of the later Middle Ages, written in straightforward prose and owing little to the native learned genres'. ${ }^{26}$ The following survey of one particular, as yet unedited, Irish compendium of medical recipes seeks to disprove at least some aspects of this assertion, first by looking more closely at the extent to which sources are explicitly acknowledged for particular elements of medical doctrine in the text, and second by considering the significance of the authorities mentioned, along with the context in which attributions to them occur, in light of the wider vernacular Irish literary tradition.

\section{The text of the Irish compendium}

Only a single complete copy of the medical compendium in question has been preserved in what was originally a single manuscript, but now survives as fragments in two separate, composite manuscripts, namely RIA MS 24 B 3 (445), pp. 33-93 and RIA MS 23 N 29 (467), ff. 1-9. The first of these codices consists of vellum fragments dating to the fifteenth and sixteenth centuries, while the second comprises twenty-three distinct sections that collectively date from the sixteenth to the eighteenth centuries. In what follows, the fragment on pp. 33-93 of RIA MS 24 B 3 will be referred to as 'B', and that on ff. 1-9 of MS $23 \mathrm{~N} 29$ will be referred to as ' $\mathrm{N}$ '.

$\mathrm{B}$ and $\mathrm{N}$ are not recognised as forming a single text in either the current published catalogue of Royal Irish Academy manuscripts or in the earlier description of $23 \mathrm{~N}$ 29 provided by Eugene O'Curry. ${ }^{27}$ The latter nevertheless devoted some attention

\footnotetext{
${ }^{25}$ Morfydd E. Owen, 'Meddygon Myddfai: a preliminary survey of some medieval medical writing in Welsh', Studia Celtica 10:11 (1975-76), 210-33, at 227-28 and 232.

${ }^{26}$ Owen, 'Meddygon Myddfai', 221.

${ }^{27} \mathrm{~K}$. Mulchrone et al., Catalogue of Irish manuscripts in the Royal Irish Academy, Vol. 2, fasciculi VI-X [MSS 253-483] (Dublin, 1931-33), 1183-85 and 1220-22 (noting only the similarity of the two fragments at 1183); Eugene O'Curry, Catalogue of Irish manuscripts of the Royal Irish Academy, First Series (RIA MS 67 E 9-11, 1841-43), i, 258-61. The description of the two fragments given in the RIA catalogue is largely based on O'Curry's earlier observations.
} 
to the portion of the compendium in N, describing it as the only part of RIA MS 23 $\mathrm{N} 29$ that was deserving of any notice, and stating that 'this fragment appears to me to be part of an original Irish treatise on medicine, because, with the exception of wine, ale, or almost [sic], all the remedies prescribed are Irish plants, herbs etc.' O'Curry also noted the peculiarity that the author of the text quotes the authority of Dían Cécht for several of the applications prescribed therein, as well as the fact that 'every prescription, after being first given in prose, is then given in very good verse' ${ }^{28}$ More recently, Aoibheann Nic Dhonnchadha has produced a revised collation of $\mathrm{B}$ and $\mathrm{N}$ that clearly demonstrates their origin as a single text, and orders the pages of the fragments in the following sequence:

$$
\begin{aligned}
& \text { RIA } 445 \text { (24 B 3), pp. 33-70 } \\
& \text { RIA } 467 \text { (23 N 29), ff. 1-4 } \\
& \text { RIA } 445 \text { (24 B 3), pp. 71-74 } \\
& \text { RIA } 467 \text { (23 N 29), ff. 6-9 } \\
& \text { RIA } 445 \text { (24 B 3), pp. 75-9329 }
\end{aligned}
$$

The scribe of both B and $\mathrm{N}$ identifies himself as Connla Mac an Leagha, who was evidently a member of the renowned hereditary medical family of that name. He was seemingly a son of one Iollann Mac an Leagha and a brother to Maelechloinn Mac an Leagha, the latter of whom served as ollam in medicine to the Mac Donnchaidh lords based in Ballymote and Tirerrill, Co. Sligo. ${ }^{30}$ According to several notes in RIA MS 24 B 3, Connla was active in 1496 and writing at his own house, probably located somewhere in the lordship of Magh Luirg (now the modern-day baronies of Boyle and Frenchpark, Co. Roscommon). A separate note on the fourth folio of N, crossed out but legible, further indicates that he copied some of the text in the Sligo parish of Killaraght, near Boyle, Co. Roscommon, in 1509, and that he was himself a practising physician at the time: ${ }^{31}$

\footnotetext{
${ }^{28}$ O’Curry, Catalogue, 259.

${ }^{29}$ Noted in print by David Stifter, 'Zur Bedeutung und Etymologie von altirisch sirem', Die Sprache 45:1-2 (2005), 160-89, at 161, n. 2. This revised collation also shows that the final portion of the compendium, found in B, in fact ends at p. 93 rather than p. 110, as stated in the published catalogue. ${ }^{30}$ See Nollaig Ó Muraíle, 'The hereditary medical families of Gaelic Ireland', in Ó Murchú, Rosa Anglica: reassessments, 85-113, and Paul Walsh, 'An Irish medical family - Mac an Leagha' in Colm Ó Lochlainn (ed.), Irish men of learning (Dublin, 1947), 206-18 (repr. from the Catholic Bulletin 25 (1935), 646-53). Walsh notes (206) that Iollann Mac an Leagha and three of his sonsMaelechloinn, Eoghan and Connla-are all mentioned in Kings Inns Library MS 15, a medical volume written by Maelechloinn in 1512 .

${ }^{31}$ Walsh, 'An Irish medical family', 215; cf. Wulff and Mulchrone, Catalogue, 1220-22. Connla signed his name on pp. 104 and 124 of RIA MS 24 B 3; on p. 94 of the same manuscript he states that he is writing at 'Granseach Muintere Fithcheallaigh', and a note on p. 109 shows that he was at 'Achaidh Lois[c]the' in 1496.
} 
Mesi Conla Mac an Lega 7 a Cill Athricht damh faré Tomaltach mac Céin [mi]c Eógain iar ngerradh a chosi gu guasachtach do Chormac [mac] Briain Óig hÍ Airt [an lu]an iar ndomnach na crosi naomda aniú 7 a cethair dég ais ésga ann 7 naoi mbliadna 7 cúic céd bliadan 7 míle bliadan aís an tigerna. Bás Diarmada mic Eógain mec Tomaltaig hí Gadra aniú 7 é ag dénam an corgais ina baile budéin iar mbreth buada [ó do]man 7 ó deman.

I am Connla Mac an Leagha, and I am in Killaraght attending on Tomaltach, son of Cian, son of Eóghan [O Gara] who has had his foot dangerously wounded by Cormac, son of Brian Óg O hAirt, the Monday following the Sunday of the Cross it is to-day, and the fourteenth of the Moon, and the Age of the Lord is 1509. The death of Diarmaid, son of Eóghan, son of Tomaltach O Gara, occurred to-day while he was performing the Lent in his own dwelling-place after having gained victory over the World and the Devil. ${ }^{32}$

Taken together, the relevant folios of $\mathrm{B}$ and $\mathrm{N}$ can be seen to constitute a single treatise comprising prescriptions for various diseases or bodily afflictions that are, for the most part, arranged in head-to-toe order. However, the text is also divided by the scribe or original compiler (if they are not one and the same) into two main sections, the first purportedly dealing with 'hot' diseases, and the second with 'cold' ones. Thus the first section of B begins with recipes for hair problems and canities, followed by cures for afflictions of the skin, ears, eyes, nose, teeth, tongue and lungs. This is continued in the first four folios of N, which also contains recipes for afflictions of the stomach. That these diseases are all classified in the treatise as 'hot' is specified in the beginning of the next section on page 71 of B, which states Cuit na teasaidechta gu nuige sin. Cuid na fuaraidechta anois; the compiler then proceeds to list prescriptions for afflictions such as atchomall ('dropsy'), cáer (? 'lump') and leic ('stones'). Folios 6-9 of $\mathrm{N}$ contain further recipes for ailments of the stomach, piles, male genitalia (mainly cures for impotence) and 'diseases of women'. The manuscript also includes two non-medical items, one a poem on the Shannon and the other a short prose account concerning the assassination of Maol Eachlainn Mág Raghnaill, chief of the small lordship of Muintear Eólais in modern-day Co. Leitrim. ${ }^{33}$ The medical treatise ends on pages 75-93 of B, which continue the section on diseases of women (sterility, childbirth, etc.), followed by

\footnotetext{
${ }^{32}$ Walsh (ed. and trans.), 'An Irish medical family', 215-16.

${ }^{33}$ The first of these non-medical items has been edited by Brian Ó Cuív, 'A poetic contention about the River Shannon', Ériu 19 (1962), 89-110. The second is edited, translated and discussed by Mícheál Hoyne, 'The assassination of Mag Rághnaill and the capture of his ship in 1502', Studia Hibernica (forthcoming); I am grateful to him for sharing a copy of this article with me in advance of its publication.
} 
prescriptions for aillse ('tumour'), lindiguin (? 'sciatica'), galar toitmech ('falling sickness', or 'epilepsy') and lubra ('leprosy').

Individual sections of the compendium are distinguished by way of pronounced incipits, many of which contain limited or no Latin, while recipes listed within each of these sections are differentiated using rubricated initials. The majority of these prescriptions are written in a straightforward prose reminiscent of the simple, terse recipe style described by Banham and Owen in relation to the Anglo-Saxon and Welsh medical collections, respectively. ${ }^{34}$ Recipes cast in verse, of which I have so far identified a total of thirty-four, are occasionally indicated by the word duan written in the left-hand margin of the manuscript, ${ }^{35}$ or by a statement within the text that a remedy is to be presented tre medaracht ('through metre') or tre filidecht ('through poetry'). ${ }^{36}$ There is, however, no explicit attribution of the text as a whole to any single Latin author, and indeed the work in its entirety rather appears to be a compilation drawing on various sources. A further indication of this is the fact that a fairly substantial number of charms have been included among the recipes in prose and verse form. Several of these charms are paralleled elsewhere, either by variant versions in other Irish manuscripts or by similar charms recorded in other medieval vernaculars. For example, the compendium ends with what appears to be a version of the charm for sleep and fever known from several other sources, including the tenth-century Old English Lacnunga collection, as the 'Seven Sleepers of Ephesus'. ${ }^{37} \mathrm{~A}$ handful of published studies have shed light on other charms found elsewhere in the compendium; however, these discussions primarily deal with the difficult language of individual charms, extracted from their surrounding context, and contain relatively little in the way of commentary concerning the contents of the compendium as a whole. ${ }^{38}$

By contrast, the following survey of authoritative attributions in Connla Mac an Leagha's compendium seeks to approach this question of the text's overarching nature and sources from a different angle, and using a somewhat wider lens. Preliminary analysis of the work has identified a total of only twenty-two

\footnotetext{
${ }^{34}$ See above, 24-26.

${ }^{35}$ As for example on p. 60 of B, where the incipits to four separate poems have been noted by the scribe. For an edition and translation of one of these poems, see Hayden, 'Three versified medical recipes', 109-10.

${ }^{36}$ E.g. B, 84.18 and 86.10 , respectively.

${ }^{37}$ See for example Cameron, Anglo-Saxon medicine, 151-53, and Wilfrid Bonser, 'The seven sleepers of Ephesus in Anglo-Saxon and later recipes', Folklore 56 (1945), 254-56; for another copy of this charm in Irish, see NLI MS G11,338b12-17. For the text of the Lacnunga, see Edward Pettit, Anglo-Saxon remedies, charms and prayers from British Library MS Harley 585: The Lacnunga. Introduction, text, translation and appendices, 2 vols (Lewiston and Lampeter, 2001).

${ }^{38}$ See, for example, James and Maura Carney, 'A collection of Irish charms', Saga och Sed: Kungliga Gustav Adolfs Akademiens Arsbok (1960), 144-52; Stifter, 'Zur Bedeutung'; id., 'A charm for staunching blood', Celtica 25 (2007), 251-54; and Jacqueline Borsje, 'Medieval Irish spells: "words of power" as performance', in Ernst Van den Hemel and Asja Szafraniec (eds), Words: religious language matters (New York, 2016), 35-53.
} 
ascriptions of doctrine to particular authorities across eighty-one pages of what is frequently quite dense (and sometimes poorly legible) script. These attributions can be broadly characterised as falling into three distinct categories: first, recognisable classical authorities (five citations); second, non-classical but (presumably) historical authorities (four citations); and third, Irish mythological authorities (thirteen citations).

\section{The citation of authorities in the compendium}

\section{Attributions to classical authorities}

When compared with a source such as the Irish translation of John of Gaddesden's Rosa Anglica, the rarity of explicit references to recognisable classical authorities in the medical compendium is striking; I have thus far identified only five such references across the text in its entirety. This list is probably not exhaustive, as the names of well-known medical authorities such as Galen or Hippocrates are often abbreviated in Irish medical manuscripts to only one or two letters, and further references to these figures may only become apparent upon closer analysis of individual sections of text. ${ }^{39}$

Three of the five attributions in question are to Dioscorides, the Greek physician of the first century A.D. whose Materia medica, a pharmacopeia in five volumes, was translated early into both Latin and Arabic and widely read in Europe, albeit often in edited or epitomised form, until as late as the seventeenth century. Cameron has noted, for example, that the work of Dioscorides was known to the compilers of the Anglo-Saxon leechbooks. ${ }^{40}$ However, Faith Wallis has pointed out the need for caution when dealing with medieval medical sources ascribed to this author in particular, as some texts that bore a generic resemblance to the Materia medica came to be transmitted under the name of Dioscorides ${ }^{41}$ All three references to this figure in the Irish medical compendium simply mention him in passing as an authority for herbal cures to combat afflictions of the hair and head, e.g. Adeir Dyascordes in ceand do nige do zūg duilleoige sīsaini ('Dioscorides says to clean the head with the juice of a leaf here below'). ${ }^{42}$

\footnotetext{
${ }^{39}$ As is the case in other Irish medical texts, 'Galen' is abbreviated in the compendium to the letter 'g' preceded and followed by a point, while Hippocrates (Ipocraid) is abbreviated to the letters 'Ip' with a suspension mark. For examples of the use of these same contractions in a separate medical work, see Séamus Ó Ceithearnaigh (ed.), Regimen na sláinte. Regimen sanitatis Magnini Mediolanensis, 3 vols (Dublin, 1942-44), i, lvi-lvii.

${ }^{40}$ Cameron, Anglo-Saxon medicine, 66.

${ }^{41}$ Wallis, 'Experience of the book', 108.

${ }^{42} \mathrm{~B}, 36.1$. The other two references to Dioscorides occur in B, 34.5-7 and 40.27. In this and the following passages cited from unedited texts, expansions are indicated by italics, and length-marks, where not found in the manuscript, have been supplied using a macron over vowels. Word-division and punctuation are editorial. Emendations designed to improve either the sense or form of the text are discussed in the accompanying footnotes. Translations, unless otherwise indicated, are my own.
} 
It is unsurprising that this same section of the compendium also contains a reference to Galen, one of the most influential Greek medical writers of the medieval period. Prior to the eleventh century, Galen's works were mostly available only second hand, and often without acknowledgement, in quotations, summaries and reworkings from the compilations of later authors. ${ }^{43}$ In this regard, it is noteworthy that, although I have thus far only identified one attribution to this figure in the compendium, the citation in question also includes reference to a specific Galenic text, namely the De morbo et accidenti ('On disease and accident'). This work is cited as a source for the doctrine that diseases can afflict the head due to the heat of the sun or air; thus it is stated in the Irish text that gallraiter uero in cenn $\overline{0}$ teas grēne nó aeir is as sin adeir Galenus in libor de morbo 7 accidenti ('The head becomes afflicted then from the heat of the sun or air, that is what Galen says in [the] book De morbo et accidenti'). ${ }^{44}$

Galen's De morbo et accidenti was the title used in the Middle Ages to refer to a compilation of four Galenic treatises: the De differentiis morborum, De differentiis symptomatum, De causis morborum and De causis symptomatum. This group of texts came to form part of the so-called 'New Galen', a collection of translations that made available for the first time several of Galen's medical works and played a central role in the medical curriculum of the early universities from the late thirteenth century onwards. ${ }^{45}$ The reference cited above from the Irish compendium may ultimately derive, at least in part, from Galen's discussion of excess heat in De causis morborum II.2, where he states that 'long periods of time spent in sunny places sometimes excessively heat the whole skin of those who are naked but the head alone of those who are clothed. This is heat-stroke. ${ }^{46}$ However, the doctrine was more likely drawn into the Irish compendium indirectly via the eleventh-century Salernitan physician Constantine the African's Viaticum, a Latin medical summa adapted from an Arabic treatise entitled Kitab Zad al-musafir wa-qut al-hadir ('The Book of provision for the traveller and nourishment for the settled') by the tenth-century Tunisian physician Khalid al-Jazzar. The Viaticum was probably originally aimed at the medical community in Salerno, but was also taught and commented on as one of the basic texts in Parisian medical education from the late twelfth century down to the early fourteenth century. ${ }^{47}$ The section on diseases of the head in Constantine's text contains a statement that corresponds

\footnotetext{
${ }^{43}$ Cameron, Anglo-Saxon medicine, 66; see also the remarks by Wallis cited above, 23-24.

${ }^{44} \mathrm{~B}, 40.4$.

${ }^{45}$ O'Boyle, Art of medicine, 6-7; for a translation of the four treatises in question, see Ian Johnston (trans.), Galen: on diseases and symptoms (Cambridge, 2006). On the introduction of the 'New Galen' into the medieval university curriculum, see especially Luis García-Ballester, 'Arnau de Vilanova (c. 1240-1311) y la reforma de los estudios médicos en Montpellier (1309): El Hipócrates latino y la introducción del nuevo Galeno', Dynamis 2 (1982), 97-158, and id., 'The new Galen,' in Klaus-Dietrich Fischer, Diethard Nickel and Paul Potter (eds), Text and tradition: studies in ancient medicine and its transmission. Presented to Jutta Kollesch (Leiden, 1998), 55-83.

${ }^{46}$ Trans. Johnston, On diseases and symptoms, 161.

${ }^{47}$ O'Boyle, 'Art of medicine', 123-24.
} 
very closely to the Irish translation cited above, namely aliquando tamen ex calore solis, uel aëris dolor est capitis. Vnde Galen. in lib. de Accident. \& morbo. ${ }^{48} \mathrm{It}$ would thus appear that the Viaticum, or a text quoting verbatim from it, was the source not only of the doctrine incorporated into the Irish compendium, but also its accompanying authorial and textual attributions. ${ }^{49}$

The only other recognisable classical figure whose name I have thus far identified in the text of Connla Mac an Leagha's compendium is the equally ubiquitous medical authority Hippocrates, who is referred to in the section of the text dealing with diseases of the lungs. The reliability of any attribution to Hippocrates is immediately suspect, of course, on the basis that the name of this figure was so well known throughout the medieval period that he was credited with the authorship of many works not actually written by him. As was the case for Galen, moreover, very few of the authentic writings of Hippocrates were available in the West in either Greek or Latin before the eleventh century, although medical writers of the early medieval period were generally happy to pay lip-service to his authority on the basis of knowledge derived from second-hand quotations and compilations. ${ }^{50}$ In this instance, the citation of Hippocrates' name forms part of a versified recipe, cast in Irish heptasyllabic deibhidhe-metre, for an affliction called loch tuile-a term which seems to be used in the compendium to refer to different kinds of pulmonary disease. ${ }^{51}$ The reference in question is not, however, an attribution in the strict sense, as is illustrated by the following poem in which it occurs: ${ }^{52}$

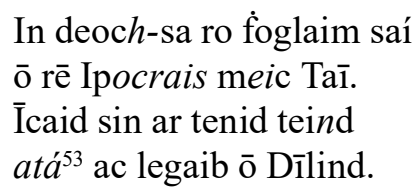

${ }^{48}$ Constantine the African, 'De morborum cognitione et curatione', in his Opera (Basel, 1539), Bk 1, Ch. 10 (De cephalea), 7.

${ }^{49}$ For a second passage in the Irish compendium that may also have been drawn from this work, see below, 41-42.

${ }^{50}$ Cameron, Anglo-Saxon medicine, 66.

${ }^{51}$ The term loch tuile is not recorded in either $e D I L$ (http://www.dil.ie, accessed 22 June 2018) or in any other published lexicographical sources for the Irish language known to me. It would appear to incorporate the u-stem noun loch meaning 'lake' or 'pool', as the genitive singular form locha is attested elsewhere in the compendium (e.g. B, 64.32); the term as a whole might thus be translated literally as something like 'a lake of flooding (?)'. Several different types of loch tuile are identified elsewhere in the compendium, including dergloch ('red loch'), glasloch ('green loch'), findloch ('clear' or 'white loch'), brénloch ('fetid loch') and tirmloch ('dry loch'). These are described as being diseases of the scamán ('lungs'), and are classified along with cosachtach ('cough'). I discuss this term and its derivatives in a separate article, 'The lexicon of pulmonary ailment in some medieval Irish medical texts', Zeitschrift für celtische Philologie (forthcoming, 2020).

${ }_{52} \mathrm{~B}, 60.25-35$. The beginning of this verse composition is clearly marked by the scribe's insertion of the word dúan in the margin of the manuscript.

${ }^{53}$ The scribe has used the Latin est-compendium here, in what would appear to be an effort to represent the corresponding form of the Irish substantive verb. 
Mes torc allaid, is lus fēin,

Criom muicci fīada a hōrslēib

crand crithach, is roga craind

a cur a soit[h]ech ālainn.

Gilcach, bun coirci lācha

bilar gusna semratha

is bentar caolfaide fai,

mongach mesca 7 midaighe.

Crocend droigin, crotoll cuill

cairt fidad 7 fīrtr[ui]m. ${ }^{54}$

craicen $n$ bentar da gach alt,

cracend firdrisi, niamnat.

A comberbad sin uili

sūg cach croind tre n-aroile.

Tabair a lestar ngrinde

gu festar a fīrinde.

Ycaid siban nach sercach,

Is $\overline{1}$ cuid gach n-aimnertach.

İcuid daorgalar gu neim

is $\overline{1}$ caid in dētiguin.

Gidbē ar a mbia loch tuile

ro-ordaig mac mōr Muire

is lōr a blasdacht guma trī.

tēit in loch tuile ar nemfní.

A wise man learned this drink

From the time of Hippocrates son of the Silent One.

That [drink] is a healer against strong fire

Leeches have had it since the Flood.

Tutsan, it is a plant itself,

Hart's tongue from the foothills

A poplar tree, it is an excellent tree

They are to be put in a beautiful vessel.

${ }^{54}$ I take this word to be a compound of the adjectival prefix fir in its extended sense of 'fresh' (for other examples, see DIL, s.v. 1 fir), and the o-stem noun trom 'elder-tree' (see DIL, s.v. 1 trom). The scribe has written the second element as -trom; however, one would expect the genitival form truim here to provide rhyme with the word cuill at the end of line a. 
Broom, a root of gentian,

Watercress with the clovers

And a slender reed ${ }^{55}$ is cut around it,

Mugwort and nightshade.

Bark of a blackthorn, bark of a hazel,

Bark of a wild cherry and [of] a fresh elder-tree.

Bark is hewn from every part,

Bark of a bramble, a tormentil.

All of these are to be boiled together

The juice of every tree mixed together

Dispense it in a fine vessel

So that its true essence may be discovered. ${ }^{56}$

A reed ${ }^{57}$ heals any lover, ${ }^{58}$

And it heals every weak person

It heals haemorrhoids with virulence

And it heals the toothache.

Whoever should have loch tuile

The great son of Mary has prescribed [this].

It is enough to take it three times,

The loch tuile disappears.

Here the classical citation in question in fact consists merely of a vague allusion to the ré Ipocrais 'age of Hippocrates', a figure who is believed to have lived sometime

\footnotetext{
${ }^{55}$ The precise meaning of caolfaide is unclear to me but it may denote some kind of reed (fead) or vine (féithleog). See, for example, Whitley Stokes, 'Three Irish metrical glossaries', Archiv für celtische Lexicographie 1 (1900), 325-47, at 335: Atriplex agrestis .i. cael feadh nó feithleog, and Tomás de Bhaldraithe, 'Roinnt lusainmneacha as foclóir an phluincéadaigh', Celtica 21 (1990), 126-45, at 137: feadh 'mariscus' (a kind of bulrush). F. E. Hogan, Luibleabrán: Irish and Scottish Gaelic names of herbs, plants, trees, etc. (Dublin, 1900), 33, gives the meaning 'honeysuckle' for feithleóg, although the genus atriplex comprises 200-300 species of plants more commonly known as 'orache'. The term caolfaide occurs elsewhere in the compendium; for examples see Hayden, 'Three versified medical recipes', 110-11.

${ }^{56}$ The word firinde could be the noun meaning 'truthfulness' or 'trustworthiness'. However, I have taken it here to be a compound consisting of the adjectival prefix fir + the noun inne 'essence, quality'.

${ }^{57}$ See $D I L$, s.v. $\operatorname{simin}(n)$, seimen(n) 'a rush, reed, corn-stalk'.

${ }^{58} \mathrm{I}$ take this to be a substantival usage of the adjective sercach 'beloved, lovable'; the sense intended here may be of the wasting caused by lovesickness, a topic that is well attested in medieval medical manuals. For an Irish example, see for example Winifred Wulff, De amore hereos, Ériu 11 (1932), 174-81; on the wider context for this doctrine, see Mary Frances Wack, Lovesickness in the middle ages. The 'Viaticum' and its commentaries (Philadelphia, 1990).
} 
between 450 and 380 B.C. This, when considered alongside the claim in line $d$ of the first stanza that the recipe has existed $o$ Dilind ('since the Flood'), makes it clear that the invocation of Hippocrates' name has in this case more to do with an attempt to underscore the antiquity and dependability of the particular recipe prescribed than with providing a factual account of its origins. The patronymic given for Hippocrates (mac Tai), which I take to be a substantival usage (in the genitive singular) of the adjective tóe 'silent' (i.e. 'son of the silent one'), was undoubtedly invented in order to rhyme with the final word of the preceding line of verse, namely sai ('sage'). It may be intended as an allusion to the fact that the name of Hippocrates' father was simply unknown to the author of the poem; comparable examples of this construction are evidenced elsewhere in Irish literary texts. ${ }^{59}$ While little reliable information has survived concerning Hippocrates' personal history, the biography of him written by the second-century physician Soranus of Ephesus gives his father's name as Heraclides. ${ }^{60}$

\section{Attributions to other historical authorities}

I have thus far identified a total of four references in the compendium to historical individuals who were not widely known authorities of the classical medical tradition but who may have been local practitioners familiar only within Ireland. The first two of these occur in poems, one on the subject of atchomall ('inflammation' or 'dropsy') and the other consisting of a cure for leprosy. The concluding stanzas of these poems refer, respectively, to a certain 'Conn Mac and Leagha' and a 'Conn Mór Mac Gilla na Naomh', to whose authority the medical knowledge conveyed in the poems is credited. In a more detailed discussion of these citations elsewhere I have noted that, as no further context is provided within the compendium that would allow for their identification, one can only speculate as to whether the two references are even to the same individual; moreover the prevalence of names such as 'Conn' and 'Gilla na Naomh' in later medieval Ireland makes it difficult

${ }^{59}$ See DIL, s.vv. 1 tóe and 2 tóe. The most famous use of the term as a patronymic is no doubt for the figure of Mac dá Thó ('son of two mutes') in the Ulster Cycle tale known as 'The story of Mac Dá Thó's pig': see Rudolf Thurneysen (ed.), Scéla mucce Meic Dathó, Mediaeval and Modern Irish Series 6 (Dublin, 1935). Other examples are also found elsewhere in early Irish literature, however; e.g. the Dindshenchas-poem on Turloch Shilinde, which refers to Blonac ingen Túi; see Edward J. Gwynn (ed. and trans.), The Metrical Dindshenchas, 5 vols (Dublin, 1903-35; repr. 1991), iii, 376-77. In the tale Talland Etair ('The siege of Howth'), moreover, the King of Leinster Mes Gegrai and his brother Mes Roída are described as da mac Da Thó in sin .i. buidir amlabair a mmáthair 7 a n-athair, 'two sons of Two Mutes, that is, their mother and father were deaf and dumb': see Caoimhín Ó Dónaill (ed.), Talland Étair: a critical edition with introduction, translation, textual notes, bibliography and vocabulary, Maynooth Medieval Irish Texts 4 (Maynooth, 2005), 45 (ed.) and 54 (trans.). O'Rahilly, Early Irish history and mythology (Dublin, 1946), 485, notes that Tó is one of the mythical ancestors of Míl, and argues that the original name of Mac Dá Thó was simply Da Tó ('the silent god'), a form 'which had become sufficiently stereotyped to be left undeclined when mac was euhemeristically prefixed to it'.

${ }^{60}$ See Johannes Ilberg (ed.), Sorani gynaeciorum libri IV, De signis fracturarum, De fasciis, Vita Hippocratis secundum Soranum, Corpus Medicorum Graecorum 4 (Leipzig and Berlin, 1927), 175. 
to provide a certain date for the individual(s) in question. ${ }^{61}$ It may be noteworthy, however, that TCD MS 1323 (H 3. 4) - a separate medical miscellany compiled in the sixteenth century, to which both the scribe of our medical compendium, Connla Mac an Leagha, and his brother Maelechloinn contributed their signatures - also mentions a certain 'Maghnus mac Gilla na Naem Micc a Leagha'. It is possible, therefore, that if such a person as 'Conn Mac Gilla na Naomh Macc an Leagha' (a brother to Maghnus?) did exist, he may have been roughly contemporary with the late fifteenth-/early sixteenth-century medical scribe of our compendium, Connla Mac an Leagha. This would indicate that the composition of at least some of the verse in the collection might have occurred as late as the fifteenth or sixteenth centuries, although the doctrine on which it is based could of course be rather older than this. It would also suggest that a member of the Mac an Leagha medical family was sufficiently trained in the art of filidecht, or a theoretical knowledge about the content, metrics and language of poetry, to render scientific doctrine into this mnemonic medium. ${ }^{62}$

The other two references in the compendium to figures who are presumably historical are equally lacking in contextual information, but nevertheless offer intriguing hints regarding the nature of local medical practice in medieval Ireland. The first occurs in the penultimate stanza of a versified recipe in eight quatrains for the ailments known as atchomall ('dropsy') and loch tuile ('pulmonary disease'):.63

Colmān mac Oililla aín

As è tug an Inis Fāil,

mar do ordaig Rīg na Rand

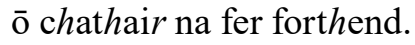

Fair Colmán son of Oilill, it is he who took the Island of Ireland, as the King of the Stars ${ }^{64}$ has ordained, from the settlement of the very strong men.

The first problem with this reference is that it is difficult to tell whether it should even be considered an authoritative attribution at all: there is no explicit statement

\footnotetext{
${ }^{61}$ Hayden, 'Three versified medical recipes', 114-15, which includes transcriptions and translations of the full stanzas in which these names occur.

${ }^{62}$ On the composition of technical poetry in the later medieval period and the distinction between filiocht and dán 'professional poetry'- the latter referring more specifically to the composition of elegies and praise-poems addressed to aristocratic patrons in return for payment - see Katharine Simms, 'The poetic brehon lawyers of early sixteenth-century Ireland', Ériu 57 (2007), 121-32, as well as my remarks in Hayden, 'Three versified medical recipes', 121-22.

${ }^{63} \mathrm{~B}, 65.33-66.5$; the penultimate quatrain occurs at 66.3 .

${ }^{64}$ See DIL, s.v. 1 rann (II), which notes that rann is sometimes used for rind 'star, point', and gives the example of 'ri na rann, 'freq. title of Deity in poetry'.
} 
to the effect that the recipe detailed in the preceding quatrains of the poem was prescribed or 'passed down' by Colmán Mac Oililla, as is typically the case for attributions found elsewhere in the compendium. The second problem concerns the identity of this individual. Annalistic sources record the obits of two figures named Colmán Mac Oililla (or Aililla), both of whom are associated with ecclesiastical centres. The first, who died in 823, is described as abb Slaine \& ecclas oile archéna isin f-Frainc \& i n-Erinn ('Colman, son of Aileall, Abbot of Slaine, and also of other churches in France and Ireland'). ${ }^{65}$ The second reference is to an individual of this name who served as abbot of Clonard and Clonmacnoise in the first half of the ninth century, and is described in his obit as a doctor egnaidh ('wise doctor'):

Colman, mac Aililla, abb Cluana Ioraird, \& Cluana Mic Nóis, espucc, \& doctor egnaidh, d'ég. As leis do-rónadh daimh liac Cluana Mic Nóis. Do Chonaillibh Muirtemhne a chenel.

An dechmhad bliadhain, dail dir, ro fher failte \& bron, Colman Cluana gair gach tuir; Albdann do dhol dar muir.

Colman, son of Ailill, Abbot of Cluain-Iraird and Cluain-mic-Nois, a bishop and wise doctor, died. It was by him the Daimhliag of Cluainmic-Nois was built; he was of the tribe of the Conailli-Muirtheimhne.

The tenth year, a just decree, joy and sorrow reigned, Colman of Cluain, the joy of every tower, died; Albdann went beyond sea. ${ }^{66}$

Byrne has suggested that this second Colmán, who was abbot of Clonard since 888 and of Clonmacnoise since 904, played an important part in the transmission of annalistic writing, and that it was during his abbacy at Clonmacnoise that the annals associated with that school became independent of the parent corpus ${ }^{67}$ Yet although the term doctor could indicate simply a 'learned man' in a more general sense, it could also refer more specifically to a 'physician', and one might therefore speculate as to whether the 'Colmán mac Oilill' invoked in one of the poems from our medical compendium might refer to this particular ninth-century abbot as one who was recognised for having possessed some form of medical expertise, in addition to his renown as an annalist and ecclesiastical scholar.

Although the evidence for this is inconclusive, the fourth and final reference in the compendium to a 'non-classical' historical figure suggests that prominent

${ }^{65}$ John O'Donovan (ed. and trans.), Annála rioghachta Éireann: annals of the kingdom of Ireland by the Four Masters, from the earliest period to the year 1616, 7 vols (Dublin, 1848-51), i, s.a. 823.8.

${ }^{66}$ O'Donovan, Annála rioghachta Éireann, ii, s.a. 924.2.

${ }^{67}$ F. J. Byrne, 'Church and politics, c. 750—c. 1100', in Dáibhí Ó Cróinín (ed.), A new history of Ireland, volume I: prehistoric and early Ireland (Oxford, 2005), 656-79, at 668-69. 
members of medieval Irish ecclesiastical communities might be directly involved in healing practices. The attribution in question occurs in the section of the compendium comprising recipes to combat the pulmonary ailment referred to as loch tuile, where it is specified that a particular cure for this condition has been procured from an unnamed 'abbot of Bangor' (B, 64.32-33: Eolus do dīchur locha tuile and sō amal frith $\bar{o}$ abaid Bendcair, 'knowledge for getting rid of loch tuile here, as it was obtained from the abbot of Bangor'). No details are given in the text itself regarding the identity of this individual or the period in which he was active. It might be noted, however, that the church of Bangor in Co. Down, to which this reference most probably alludes, was renowned as a major centre of learning from its foundation by St Comgall in the second half of the sixth century ${ }^{68}$

Little has yet been established regarding the nature of ecclesiastically based medical practice in Ireland, particularly during the early medieval period. However, it may prove useful to consider the two possible references to ecclesiastical figures discussed here in light of the evidence for medical practitioners in late Anglo-Saxon England, who are known to have frequently been associated with monasteries. ${ }^{69}$ The identification of an unnamed 'abbot of Bangor' as the source of one particular recipe might also be compared to the aforementioned references in Bald's Leechbook to the otherwise-unknown authorities Dun and Oxa. ${ }^{70}$ As noted by Banham, while we can say virtually nothing about the identity or activities of these individuals, the casual references to them in a compendium of medical recipes may indicate that the readers of the Old English text were simply expected to know who Dun and Oxa were and to recognise their authority. ${ }^{71}$ In other words, despite the fact that its contents are for the most part of anonymous origin, the Irish compendium nevertheless provides us with what would appear to be an occasional tantalising glimpse of medical practice at a local level.

\section{Mythological authorities}

The most substantial, and in many ways most intriguing, category of authoritative attributions in the compendium comprises invocations of Irish mythological figures. All but two of the thirteen such references that I have thus far identified cite Dían Cécht, the physician of the supernatural race known as the Túatha Dé Danann, and thus described by Binchy as "the Irish Aesculapius. ${ }^{72}$ Dían Cécht is perhaps best known from his role in the medieval Irish narrative tale Cath Maige Tuired, which

\footnotetext{
${ }^{68}$ See Bedwyr Lewis Jones, 'Why Bangor?', Ainm 5 (1991-93), 59-65, where it is observed (63-64) that variants of the form Bennchor are found in Irish annals up to $c .1250$, with the earliest attestation being in the seventh-century Antiphony of Bangor. However, many of those same annals also refer to the Welsh Bangor, for which the form is also Bennchor.

${ }^{69}$ Audrey Meaney, 'The practice of medicine in England about the year 1000', Social History of Medicine 13.2 (2000), 221-37, at 223-24.

${ }^{70}$ See above, 25.

${ }^{71}$ Banham, 'Dun, Oxa and Pliny', 67.

${ }^{72}$ Binchy, 'Bretha Déin Chécht', 4.
} 
tells of the contention between the gods of the Túatha Dé Danann and the Fomoiri that culminated in a battle said to have been fought at Moytirra (Magh Tuireadh), a plain located to the east of Lough Arrow in Co. Sligo. The most detailed account of this conflict is only preserved in a single sixteenth-century manuscript, but Gerard Murphy argued that it was 'a composite work put together by an eleventhor twelfth-century redactor mainly from ninth-century material' ${ }^{73}$ One particularly well-known episode in the tale recounts how Dían Cécht forged an artificial silver hand for the wounded King Núadu. However, his son Míach subsequently managed to surpass his father's skills in leechcraft by reciting a charm over the king's damaged limb, thereby transforming it into a fully functioning arm. Dían Cécht then killed his offspring out of jealousy, and 365 herbs grew over Míach's grave. The god's daughter, Airmed, attempted to gather and sort these according to their properties, but her father thwarted her efforts by mixing them cona fesai a frep[th] ai córi manis-tecaisceth an Spirut iar tain ('so that no one knows their healing properties unless the Holy Spirit taught them afterwards'). ${ }^{74}$ The depiction of Dían Cécht's medical expertise in Cath Maige Tuired is admittedly allusive and it is perhaps unsurprising that the scene in question has hitherto been analysed largely as evidence for the wider function of the narrative as an exemplary tale, for its contribution to our understanding of the Irish dimension of Celtic myth (e.g. as a version of the 'Generation Conflict'), or for the Indo-European reflexes of the charm recited by Míach over Núada's damaged limb. ${ }^{75}$

Outside of narratives connected to Cath Maige Tuired, Dían Cécht's association with medical lore is similarly symbolic in nature. His authority is called upon, for example, in one of the four so-called 'St Gall Incantations', a collection of charms preserved on a single leaf of eighth- or ninth-century Insular vellum that may have once formed part of a pocket Gospel book, but is now found in St Gall MS 1395. One of these charms, which purports to remedy various types of ailments or

${ }^{73}$ Gerard Murphy, Saga and myth in ancient Ireland (Dublin, 1955), 19, cited by Tomás Ó Cathasaigh, 'Cath Maige Tuired as exemplary myth', in Pádraig de Brún, Seán Ó Coileáin and Pádraig Ó Riain (eds), Folia Gaedlica: essays presented by former students to R. A. Breatnach (Cork, 1983), 1-19, at 1. For the text, see E. A. Gray (ed. and trans.), Cath Maige Tuired. The second battle of Mag Tuired, Irish Texts Society 52 (London, 1983).

${ }^{74}$ Ibid., 32-33 (\$§33-35). The agricultural associations of the healing art are reflected in the fact that the names 'Airmed' and 'Míach' are also attested as common nouns referring to dry measures: for examples, see $D I L$, s.vv.

${ }^{75}$ See, for example, Ó Cathasaigh, 'Cath Maige Tuired as exemplary myth', and id., 'Pagan survivals: the evidence of early Irish narrative', in Michael Richter and Próinséas Ní Chatháin (eds), Irland und Europa: die Kirche im Frühmittelalter / Ireland and Europe: the early church (Stuttgart, 1984), 291-307. The context and parallels for Míach's charm are discussed by Jaan Puhvel, 'Mythological reflections in Indo-European medicine', in George Cardona, Henry M. Hoenigswald and Alfred Senn (eds), Indo-European and Indo-Europeans (Philadelphia, 1970), 369-82, and also by Calvert Watkins, How to kill a dragon. Aspects of Indo-European poetics (Oxford, 1995), 525-36. For the most recent assessment of this particular episode, which suggests that Míach's intervention was intrusive to the original narrative, see Edward Pettit, 'Míach's healing of Núadu in Cath Maige Tuired', Celtica 27 (2013), 158-71. 
wounds, invokes the name of Dían Cécht when calling for the application of a salve that he had 'left with his people' (Ad-muinur in slánicid fo-r-acab Dian Cecht lia muintir corop slán ani forsa-te, 'I put my trust in the salve which Diancecht left with his people that whole may be that whereon it goes'). ${ }^{76}$ The most famous invocation of the god's name as a symbol of medical authority outside of the corpus of saga-literature, however, is no doubt the title of the aforementioned Old Irish tract on the compensation due for various injuries known as Bretha Déin Chécht ('The Judgements of Dían Cécht'), which appears to have originally formed part of a group of four 'craft-judgements', attributed to various gods of the Túatha Dé Danann, that were included in the seventh-century Senchas Már legal collection. ${ }^{77}$ Yet aside from the fact that the authority of Dían Cécht is noted occasionally in the glosses and commentary to the main text of Bretha Déin Checht, ${ }^{78}$ his association with the contents of the tract on injuries is of a rather general nature, since its opening words state simply that the entirety of what follows is considered to constitute bretha dein checht o legib ('the judgements of Dían Cécht concerning leeches'). ${ }^{79}$ As I have argued elsewhere, this title-which consists of a heptasyllabic line - may have been a much later addition to the tract, possibly drawn directly from a twelfth-century didactic poem on the authors and laws of Ireland ${ }^{80}$ Nevertheless, the attribution is significant in that it demonstrates how medieval Irish legal scholars might draw on elements of mythological tradition in a manner that is comparable to what occurs in Connla Mac an Leagha's medical compendium.

Of the eleven ascriptions to Dían Cécht that I have found in the medical text, five occur in sections dealing with afflictions of the head and neck. One of these forms part of a passage on the two ways in which the head can become diseased,$^{81}$ while the second cites Dían Cécht's name in relation to a herbal prescription for carraige ('scabies' or 'mange'). In the latter case, Dían Cécht is simply said to acknowledge

\footnotetext{
${ }^{76}$ The charms were first edited by Whitley Stokes and John Strachan, Thesaurus palaeohibernicus. A collection of Old-Irish glosses, scholia, prose and verse, Volume 2 (Cambridge, 1903; repr. Dublin, 1987), 249. For further discussion, see John Carey, 'Téacsanna draíochta in Éirinn sa mheánaois luath', in Ruairí Ó hUiginn (ed.), Breis faoinár ndúchas spioradálta: Léachtai Cholm Cille 30 (Maynooth, 2000), 98-117, and Ilona Tuomi, 'Parchment, praxis and performance of charms in early medieval Ireland', Incantatio 3 (2013), 60-85.

${ }^{77}$ Liam Breatnach, A companion to the Corpus Iuris Hibernici (Dublin, 2005), 303-4, has noted that the list of component tracts found in the introduction to the Senchas Már includes a reference to a tract called Bretha Creidini together with the 'craft-judgements' of Dían Cécht, Goibniu and Luchtaine. Creidine appears in Cath Maige Tuired as the bronze-worker of the Túatha Dé Danann, alongside Goibniu (the smith), Dían Cécht the physician, and Luchta/Luchtaine, the wright (Gray, Cath Maige Tuired, $\S \$ 96-103)$.

${ }^{78}$ See Binchy, 'Bretha Déin Chécht', 32-33 (\$16); 36-37 (§22); 40-41 (§30); 42-43 (§33); and 46-47 (\$35).

${ }^{79}$ Ibid., 22-23.

${ }^{80}$ Hayden, 'Three versified medical recipes', 118-19.

${ }^{81}$ B, 39, lines 22-23: is uime sin adeir Dian Cēcht danō gallraiter an cenn ('it is because of that that Dían Cécht says the head becomes diseased').
} 
the fact that the cure in question would be beneficial for the brain (B, 41.23-24: et derbaid Dyan Cēcht gurob tarbach don incinn sin). A third attribution occurs at the end of a prose recipe for galar cinn (literally 'disease of the head', but probably referring to 'headache'), where the scribe has written only ut dixit Dian (B, 44.12). Omission of the second element in Dían Cécht's name occurs again in a fourth attribution found in the opening line of the section on afflictions of the neck, which reads [C]ollum .i. an muinēl mar ader dīan. ${ }^{82}$

The fifth attribution to Dían Cécht in this portion of the compendium is particularly interesting, not least because it provides what would seem to be a rare example of fairly elementary anatomical learning in the text. Here the healer figure is cited as an authority for the doctrine that there are four divisions of the head, each of which contains a different humour (B, 39z-40.3):

Bīd a f[h]is agut gu fuilet 4 ranna isin cenn, amal adeir Dyaan Cēcht in lebor institucionum ${ }^{83}$ gu foguilter an cend a ceithri randaib 7 tigernaid linn in gach rand dib[h] sin .i. fuil dearg isin édan, linn rúad sa taob[h] des $>$ linn dubh sa taobh clé [7] linn finn sa cúlincind, 7 dligid in līaig fricnum ag at $h$ ne na teg $h$ mann donīter uat $h$ u sin.

Let you know that there are four parts in the head, as Dían Cécht the physician says in the book of instructions that the head is divided into four parts, and a humour rules in each of those parts, i.e. red blood (sanguine humour) in the forehead, red humour (choler) in the right side and black humour (melancholy) in the left side, [and] white humour (phlegm) in the occiput, and the physician should practise while knowing the ailments that are caused by those.

As was shown to be the case for the passage discussed above concerning heat and cold as causes of ailments affecting the head, the ultimate source of this excerpt again appears to be Constantine the African's Viaticum: ${ }^{84}$

Galenus in libro Institutionum: nosse oportet caput diuidi in quatuor partes: sanguis in fronte dominat. Cholera rubea in dextra parte. Phlegma in occipite. Cholera nigra in sinistra. In quibus cognoscendis medicus opera dabit.

\footnotetext{
${ }^{82}$ B, 58.24; on the possible significance of this omission, see my remarks below, n. 102 .

${ }^{83}$ The manuscript here reads instituconum with a suspension mark over the 'c'. It seems to me most likely that the scribe intended to write $c i$ for $t i$, as this was a standard feature of medieval Latin spelling: see Pádraig A. Breatnach, 'The pronunciation of Latin in medieval Ireland', in Sigrid Krämer and Michael Bernhard (eds), Scire litteras: Forschungen zum mittelalterlichen Geistesleben, Bayerische Akademie der Wissenschaften, Phil.-Hist. Kl., Abhandl. NF, Heft 99 (Munich, 1988), 59-72, at 69 .

${ }^{84}$ See above, $31-32$.
} 
Galen [says] in the book of instructions: one should know that the head is divided into four parts. Blood dominates in the forehead, choler in the right part, phlegm in the occiput, melancholy in the left. In knowing which things, the physician will perform his work. ${ }^{85}$

This passage is similar to the first excerpt cited from the Viaticum in that it presents a very close translation of Constantine's Latin text into Irish. ${ }^{86}$ The key difference between the two citations is that, in the first, the Irish translator can be seen to have faithfully preserved Constantine's original attribution to Galen's De morbo et accidenti. Here, by contrast, he has claimed that the doctrine derives not from the 'Liber Institutionum' of Galen, as in the original Latin text, but rather from the 'Liber Institutionum' of Dían Cécht. Given the overall faithfulness of both Irish translations, it is probably safe to assume that the substitution of Dían Cécht's name for that of Galen in the second citation was deliberate, and not merely an attempt to fill an authoritative void. The rather more problematic question, of course, is why the original translator, or a later compiler of the text, might have felt compelled to introduce such a change. Does the alteration reflect an attempt to make the contents of the medical compendium resonate more strongly with an Irish audience assumed to be familiar with the figure of Dían Cécht and narratives relating to the Túatha Dé Danann? At a minimum, it suggests a close acquaintance on the part of the translator or compiler with aspects of the wider early Irish mythological tradition.

In this vein, one might wonder whether there is any significance in the fact that five of the eleven attributions to Dían Cécht occur in the section of the compendium dealing with diseases affecting the head and neck, given that the god is specifically associated with this part of the anatomy in Cath Maige Tuired. The narrative dramatically details how Dían Cécht first struck three non-mortal blows to his son Míach's head, penetrating as far as the flesh, bone and membrane, respectively; it is said to be only when the god's weapon penetrated the most vulnerable part of the head, namely the brain (inchinn), that he succeeded in killing his offspring. ${ }^{87} \mathrm{~A}$

\footnotetext{
${ }^{85}$ Constantine the African, 'De morborum cognitione et curatione', 7. It is possible, of course, that the Irish translator was working from a later source that quotes Constantine's text verbatim. An example of this is found in the thirteenth-century Franciscan scholar Bartholomaeus Anglicus' De proprietatibus rerum, an encyclopedia completed around 1245 that contains a nearly identical passage within a discussion of the causes and signs of headache. For a translation of the relevant part of this text, see Faith Wallis, Medieval medicine: a reader, Readings in Medieval Civilizations and Cultures 15 (Toronto, 2010), 249. Wallis traces the ultimate source of the doctrine in question to Galen's tract On compounding medicines according to place 2.1. It is clear from his use of authorial attributions, however, that Bartholomaeus has himself drawn the passage from Constantine's Viaticum.

${ }^{86}$ On the first passage, see above, 32.

${ }^{87}$ For further discussion of this passage, see Deborah Hayden, 'Observations on the "doors of death" in a medieval Irish medical catechism', in Ó Murchú, Rosa Anglica: reassessments, 26-56, at 38-40. The phrasing of this episode in Cath Maige Tuired may be somewhat formulaic,
} 
counterweight to this suggestion is provided, however, by the fact that references to the authority of Dían Cécht also occur in sections of the compendium containing cures for other parts of the anatomy. Thus, for example, the god's name is also invoked in a recipe for various ailments of the chest that is claimed to have been prescribed by ar n-oitde ('our teacher') — a phrase which is glossed with the name of Dían Cécht (N, 1v11-12):

Brasech an $n$ so do ordaigh ar n-oitde .i. Dian Cēcht ar leic 7 a $r$ cāir 7 ar mēt mbronn 7 ar at mbrond...

A pottage here which our teacher, i.e. Dian Cécht, has prescribed for stone and for cáer (? 'lump') and for mét mbronn (? 'greatness of the chest') and for at mbrond ('swelling of the chest') ...

On the following folio, another invocation of Dían Cécht's name introduces a series of recipes for abdominal afflictions (N, 2vl: do gallraib an gaile, is laburta düin fesda amail adeir Dīan Cécht, 'concerning illnesses of the stomach, it is to be discussed by us now as Dían Cécht says'). In both of these instances, it would appear that Dían Cécht's name has simply been supplied in the absence of any other known authority for the cures in question.

The remaining invocations of Dian Cécht's name that I have thus far identified in Connla Mac an Leagha's medical compendium occur in recipes cast in metrical form. Three of these poems, which consist of recipes for chest ailments, slimming and urinary disease, respectively, I have published in full elsewhere. ${ }^{88} \mathrm{~A}$ fourth poem of ten quatrains, consisting of a recipe for abdominal sickness (bronngalur), likewise refers in its final stanza to the 'teaching of Dían Cécht' (tecusc Dìan Cecht):

Tecusc Dian Cēcht, a curp glan

do neoch i $m$ bí bronngalur.

Scet[h]rach grīsi, litiu gan geis

brochān is praisech leighis ...

The teaching of Dían Cecht, in a pure body

for anyone in whom there is abdominal sickness.

however: compare, for example, the description in the Welsh romance Iarlles y ffynnawn, which recounts how Owain inflicted a mortal blow on the Black Knight by striking him trwy y kroen a'r kig a'r asgwrn yny glwyfawd ar yr emennyd ('through the skin, flesh, and bone until it wounded the brain'): see R. L. Thompson (ed.), Owein or chwedyl iarlles y ffynnawn, Mediaeval and Modern Welsh Series 4 (Dublin, 1968), 11. See also the remarks by Watkins, How to kill a dragon, 539.

${ }^{88}$ Hayden, 'Three versified medical recipes', 109-13. 
Vomiting of fever, ${ }^{89}$ a porridge without prohibition A healing broth and pottage ... ${ }^{90}$

While the vast majority of mythological attributions in the compendium invoke the name of Dían Cécht, it is interesting that the text also contains two further attributions of doctrine to other figures of the Túatha Dé Danann. In the first of these, Dían Cécht's son Míach - the aforementioned healer and victim of filicide in Cath Maige Tuired - is cited alongside the Dagda as an authority for the entire collection of prescriptions for eye ailments (B, 48.12-13):

De dolore oculorum .i. do galruib na sūl 7 is iat so iat mar derbus Mīach mac Dian Cēcht do bī ag leiges Eochach Ollathar .i. in Daga ...

On diseases of the eyes, and these are as follows, as Míach, son of Dian Cécht, has attested to belong to the healing art of Eochu Ollathair, i.e. the Dagda ...

Elsewhere, the authority of Míach is again credited - this time alongside that of a certain 'Oirbea' - as the source of all the doctrine in the text relating to afflictions of the skin (B, 36.13: Do gallraib na tunde ann so sis mar adeir Mīach 7 Oirbea 7 is iat so iat; 'on diseases of the skin here below, as Míach and Oirbea say, and these are as follows'). It is probable that the name given as 'Oirbea' is simply a rendering of either 'Airmed', Míach's sister in Cath Maige Tuired, or 'Oirmíach', the physician (and possibly in essence the same figure as Airmed) who appears alongside Míach in the Early Modern Irish tale Oidheadh Chloinne Tuireann ('The Violent Death of the Children of Tuirenn'). This text, which recounts the murder of the Túatha Dé Danann king Lug's father at the hands of the sons of Tuireann and their subsequent death, can be dated on linguistic grounds to a somewhat later period than Cath Maige Tuired, having probably first been composed in the thirteenth or fourteenth centuries, although it clearly draws on elements known from the earlier text. ${ }^{91}$

\footnotetext{
${ }^{89}$ DIL, s.v. grís, gives as primary definitions of this term 'heat, fire, embers, ashes'. The word is used in relation to abdominal sickness (bronngalar) in a ninth-century triad; see Kuno Meyer (ed. and trans.), The triads of Ireland, Royal Irish Academy Todd Lecture Series 8 (Dublin, 1906), 28-29, §224: Trí galair ata ferr sláinte: seola mná for mac, gríss bronngalair glanas broinn, gríss timgaire olc dia maith ('Three illnesses that are better than health: the lying-in of a woman with a male child, the fever of an abdominal disease that clears the bowels, a feverish passion to check evil by its good'). ${ }^{90} \mathrm{~N}$, f. 4r19-20; the poem begins at line 8 .

${ }^{91}$ Caoimhín Breatnach, 'Oidheadh Chloinne Tuireann agus Cath Maige Tuired: dhá shampla de mhiotas eiseamláireach', Éigse 32 (2000), 35-46, at 43. For the text, see Eugene O'Curry, 'The fate of the children of Tuireann', The Atlantis: or register of literature and science of the Catholic University of Ireland 4 (1863), 157-240; Richard J. O'Duffy (ed. and trans.), Oidhe Chloinne Tuireann: the fate of the children of Tuireann (Dublin, 1888; repr. 1901); James Patrick Craig (ed.), Clann Tuireann, being a modern version of the fate of the children of Tuireann (Dublin, 1902); Seán Ua Ceallaigh
} 
As is the case for Dían Cécht, the significance of the figures of Míach and his sibling or doublet (Airmed/Oirmíach/Oirbea) for the contents of a compendium of herbal cures is not difficult to perceive when one considers their portrayal in Cath Maige Tuired as healers and practitioners of herbal medicine. The motivation underlying a reference to the Dagda in this context is rather less obvious, but may simply stem from the latter's depiction as an ancestral figure of the Túatha Dé Danann (as indicated by the epithet Ollathair 'great father'), possibly one possessing some kind of agricultural function considered relevant to the cultivation of medicinal herbs. For instance, he is described in the ninth- or tenth-century saga-narrative Tochmarc Étaine ('The Wooing of Étain') as a ri amra for Eirinn do T[h]uathaib De a c[h]enel, Eochaid Ollathar a ainm. Ainm n-aill do dano an Dagda, ar ba hé dognith na firta 7 conmidhedh na sina 7 na toirthe doib ('a famous king of Ireland from the race of the Túatha Dé, Eochaidh Ollathair his name. He was also named the Dagda [i.e. good god], for it was he that used to work wonders for them and control the weather and the crops'). ${ }^{92}$

However, the invocation of Míach's name in relation to the portions of the text dealing with skin and eye diseases, respectively may also constitute a more pointed allusion to medieval Irish literary tradition. It is conceivable, for example, that the association of this figure with cutaneous ailments was intended to recall the charm that Míach recited over Núada's damaged limb in Cath Maige Tuired, where it is specified that for a period of three days and nights the healer 'put it [the arm] over against his side, and it became covered with skin' (immuscurid comair a táeib, 7 rotonigestar). ${ }^{93}$ Similarly, Míach is depicted in Oidheadh Chloinne Tuireann as having knowledge of herbs that would cause skin to grow, as he asks Oirmiach whether he would prefer to reattach Núada's original arm by setting the bones or by gathering herbs doćum feola do ćur uirre ('to put flesh upon it'). ${ }^{94}$ The later narrative also provides some support for Míach's association with diseases of the eyes, since, prior to treating King Núada's arm, he and Oirmíach are also claimed to have been responsible for resolving a problem of a specifically ocular nature: namely, they restored full vision to the king's one-eyed doorkeeper with the use of a cat's eye. In keeping with the tale's rather more satirical portrayal of the Túatha Dé

(ed.), Tri truagha na scéaluidheachta: Oidhe chlainne Tuireann, Oidhe chlainne Lir, Oidhe chlainne Uisnigh (Dublin, 1927). See also Rudolf Thurneysen, 'Tuirill Bicrenn und seine Kinder', Zeitschrift für celtische Philologie 12 (1918), 239-50.

${ }_{92}$ Osborn Bergin and R. I. Best (eds and trans.), 'Tochmarc Étaíne', Ériu 12 (1938), 137-96, at 142-43; see also the remarks by O'Rahilly, Early Irish history and mythology, 469-70.

${ }^{93}$ Gray, Cath Maige Tuired, 32-33 (\$33). The correspondence of terminology here may be noteworthy: the word used to refer to 'skin' in the above-cited attribution to Míach (beginning do gallraib na tunde) is the a-stem noun tonn. The DIL gives a primary meaning of 'wave', with 'surface' or 'skin' only listed as secondary definitions: see DIL, s.v. tonn II(d). However, under a separate entry the dictionary also gives the form rotonigestar, drawn from the text of Míach's charm in Cath Maige Tuired, and suggests that this is the sole attestation of a reconstructed verb tonnaigid 'covers with skin': see DIL, s.v. ?tonnaigid.

${ }^{94}$ O’Duffy, Oidhe Chloinne Tuireann, 3 (ed.) and 69 (trans.). 
Danann, this cure is described as having been 'both convenient and inconvenient' for the doorkeeper, since

... an trát do b’áil leis codlad nó comsanad do déanam, is annsin do bíodgad an t-súil le greadair na luc, agus le h-eiteall na n-eun, agus le gluasac̀t na sibinne; agus an trát ba mian leis feitiom sluag no oireaċtais do déanam, is annsin do biod 'na toircim suain agus codalta aige.

... when he desired to take sleep or repose, then the eye would start at the squeaking of mice, the flying of the birds, and the motion of the reeds; but when he desired to watch a host or an assembly, then it is that it would be in deep repose and sleep. ${ }^{95}$

It is tempting to suggest that the author or compiler of the sections of the medical compendium dealing with skin and eye ailments, respectively might have been in some way cognisant of these literary episodes relating to Míach, and deliberately chose to allude to them when invoking the authority of this comparatively minor figure of Irish mythology in preference to that of the otherwise more widely attested Dían Cécht. At the very least, these last two examples indicate that the compiler or scribe in question was familiar not merely with the figure of Dían Cécht as the principal god of healing in Irish literary tradition, but also had a broader acquaintance with the complex of narratives concerning the gods of the Túatha Dé Danann and the battle of Magh Tuireadh, which evidently enjoyed a certain popularity in Irish oral and written tradition in both the earlier and later medieval periods.

\section{The dating of the mythological attributions}

It is difficult to determine an absolute date for the addition of these mythological attributions across various sections of Connla Mac an Leagha's medical compendium. For one thing, it is not even necessarily the case that all such attributions were incorporated into the compilation at the same time. It is possible, for example, that the invocations of Dían Cécht's name in several of the versified recipes, which appear to have been composed as a kind of didactic 'school verse' for mnemonic purposes, inspired a later copyist - perhaps even Connla Mac an Leagha himself - to add similar mythological attributions to individual prose recipes or section incipits within his compilation. However, didactic verse such as that found in the compendium is itself challenging to date on strictly linguistic grounds, and clues to the authorship of such poems are often lacking. ${ }^{96}$ The reference to Míach as an authority for ailments of the eyes would seem to echo

\footnotetext{
${ }^{95}$ Ibid., 2 (ed.) and 68 (trans.). On the satirical portrayal of the Túatha Dé in the text, see Breatnach, 'Oideadh Chloinne Tuireann', 37-39.

${ }^{96}$ On this issue, see Hayden, 'Three versified medical recipes', 113-15.
} 
a narrative tale (Oidheadh Chloinne Tuireann) that survives in a written version only composed in the thirteenth or fourteenth centuries, but this does not mean that the episode in which the healer replaces the eye of the king's doorkeeper was not known in earlier oral tradition. The most reliable clue to this problem of dating the mythological attributions in the compendium is no doubt provided by the substitution of the name of Dían Cécht for that of Galen in the Irish translation of an excerpt from Constantine the African's Viaticum. Constantine completed his Latin text while in the Italian monastery of Monte Cassino, at some point between his arrival there - c.1060 - and his death around 1087. This provides, of course, a firm terminus post quem for the Irish translation of his work and, presumably, for the mythological attribution given in the latter. It is probable, moreover, that the Irish translation of the Viaticum would only have been produced somewhat later-most probably in the twelfth or thirteenth centuries, when the Latin work was being taught and commentated on extensively in Continental (particularly French) universities. ${ }^{97}$

The question remains, however, as to exactly what might have motivated the scribe or compiler of our compendium to incorporate so many references to Irish mythological tradition into his text, in a manner that sets this particular medical compilation apart from many other Irish vernacular translations and adaptations of scientific works. In broad terms one might, of course, view ascriptions to figures such as Dían Cécht, Míach, 'Oirbed' (or Airmed/Oirmíach) and the Dagda with regard to the wider function of myth as a means of explaining the origins, and justifying the continuation, of particular customs and practices. In the absence of any other known authority, the efficacy of a given cure could be invested with the sanction of hallowed antiquity by tracing its origins to the medicinal expertise of some famous mythological figure. ${ }^{98}$ I have argued previously that the propensity for calling upon the authority of Dían Cécht in versified recipes such as those found in the compendium may reflect the participation of medical scholars in a broader trend amongst medieval Irish literati-recently illustrated by Mark Williams in his wide-ranging study of the Túatha Dé Danann-whereby particular mythological figures were identified as patrons and personifications of the professional skills proper to the áes dána ('people of art/talent'), or those in early Irish society who maintained themselves by the exercise of their skill and knowledge. ${ }^{99}$ Williams has highlighted the role that pseudo-historical sources such as the eleventh-century compilation Lebor Gabála Érenn played in promoting the idea that certain members of the Túatha Dé were the progenitors of particular learned disciplines and skills, including medicine. It is explicitly stated in the Lebor Gabála, for example, that cach ndiamuir ndāna 7 in cach lēire leighis 7 in

\footnotetext{
${ }^{97}$ See O'Boyle, Art of Medicine, 24n and 110. O'Boyle also notes, however, that the Viaticum is rarely found in manuscripts after the first few decades of the fourteenth century.

${ }^{98}$ Cf. the comments by Ó Cathasaigh, 'Cath Maige Tuired as exemplary myth', 9.

${ }^{99}$ Mark Williams, Ireland's immortals: A history of the gods of Irish myth (Princeton, NJ, 2016), 172; cf. my remarks in Hayden, 'Three versified medical recipes', 120.
} 
cach amaindse elathan do chüisin is ō Thüathaib Dē Danann atā a bunadh ('every secret of skilful art, and every technique in medicine, and every trade-secret in poetry - all indeed derive their origin from the Túatha Dé Danann'). ${ }^{100}$ That such doctrine came to form part of the discourse of a learned elite, conversant in both Latin and the Irish vernacular, is further illustrated by the inclusion of Latin names and attributes for various members of the Túatha Dé in the eleventh-century pseudo-historical work known as the Lebor Bretnach, an adaptation into Irish of the ninth-century Cambro-Latin Historia Brittonum ('History of the Britons'). In that context, Dían Cécht is specifically identified as the chief physician (medicus) among the Túatha Dé Danann:

Rogab in n-Eirind iardain Plebes Deorum .i. Tuatha De Donann. Is dib robadar na prim-elathnaig, edon Luchtenus artifex, Credenus figal $u$ s, Dianus meidicus, Eadan filia eius .i. muimi na filed, Goibnen $n$ faber, Lug mac Eithne, ga rabadar na h-uili dana, Dagda mac Ealadan meic Delbaith in rig, Ogma brathair in rig, as e aranig litri na Sgot.

After that the plebes deorum [god-peoples], i.e. the Túatha Dé Danann, conquered Ireland. Among them were the chief skilled ones: Etan; Luchtaine Artifex [the Artificer]; Credne Figulus [the Craftsman]; Dían (Cécht) Medicus [the Physician]—Etan moreover was filia eius [his daughter], i.e., the fostermother of the poets; Goibnenn Faber [the Smith]; Lug son of Eithne, who possessed all the arts; the great Dagda, son of Elatha, son of Delbaeth, the king; Ogma, the king's brother-he it was who invented the alphabet of the Irish. ${ }^{101}$

Williams views origin-legends of this nature as a kind of "meta-mythology for intellectuals, a local analogy to the myriad ways that the classical deities were put to use by poets and thinkers throughout the Middle Ages, and beyond'. ${ }^{102}$ The question of whether medieval Irish scholars actually believed in the mythological figures whose authority they invoked in didactic poems and other learned texts is a vexed one, but the fact that such authority was not seen to conflict with the firmly Christian milieu in which this material was first written down is evident from the

\footnotetext{
${ }^{100}$ R. A. S. Macalister (ed. and trans.), Lebor Gabála Érenn, Irish Texts Society 34, 35, 39, 41 and 44 (London, 1938-56), iv, 164-65.

${ }^{101}$ A. G. Van Hamel (ed.), Lebor Bretnach: The Irish version of the Historia Britonum ascribed to Nennius (Dublin, 1932), 21-2; trans. Williams, Ireland's immortals, 171-72. It is interesting, in light of the apparent omission of the element 'Cécht' from the healer's name in two of the attributions from our medical tract cited above (41), that the Latin form of Dían Cécht's name in the Historia Brittonum is given simply as Dianus. One wonders whether the two references to 'Dian' in the medical compendium are really the result of an error or omission on the part of the scribe, or rather simply reflect familiarity with the Latin form of his name.

${ }^{102}$ Williams, Ireland's immortals, 181.
} 
fact that the mac mór Muire ('great son of Mary') is likewise cited as a source in the final stanza of the versified recipe edited above. ${ }^{103}$

The idea that the references to the Túatha Dé Danann in this medical compendium might constitute an attempt to create a 'local analogy' to a much wider European scientific tradition - one to which the contents of the compendium are, in other respects, heavily indebted - also finds support when one considers the historical and geographical origins of the manuscript itself. As has been noted above, the principal scribe of the compendium, Connla Mac an Leagha, was a member of a hereditary family of medical practitioners based primarily in north Connacht and attested in written sources from at least the fifteenth century. Connla is known to have copied at least part of his compendium while residing in the lordship Magh Luirg, Co. Roscommon, and Walsh has suggested that he may have been subject to one of the Mac Diarmada rulers of that region - possibly in the capacity of a practising physician, much like his brother Maelechloinn, who was employed as an ollam in medicine to the Mac Donnchaidh lords in nearby Ballymote and Tirerrill, Co. Sligo. ${ }^{104}$ The local connections of the scribe are also reflected in one of the two non-medical items included in his manuscript, namely the short prose account concerning the murder in 1502 of the Leitrim-based Maol Eachlainn Mág Raghnaill: an act that was, as Mícheál Hoyne has recently shown, instigated by the Mac Diarmada family. ${ }^{105}$

In addition to his edition of this prose account, however, Hoyne has also demonstrated a further, and in the present context even more compelling, link between the Meic Dhiarmada of Magh Luirg and the scribal activities of individuals to whom they served as patrons. In his study of a later (Early Modern Irish) version of the mythological tale Cath Maige Tuired, extant in a single manuscript copy, he has argued that the reworked version of the narrative appears to have been circulating among the Uí Dhuibhgeannáin family of poet-historians based in Cill Rónáin, Co. Roscommon during the early fifteenth century, and may have been compiled by them for their primary patrons, the Meic Dhiarmada of Magh Luirg. ${ }^{106}$ Hoyne describes this later version of Cath Maige Tuired as 'a sophisticated work of propaganda produced by a well-informed scholar for his patron', in which the struggles of the Túatha Dé with the Fomorians on the plain of Magh Tuireadh serve to reflect the contemporary political struggles in which the Meic Dhiarmada were involved. Indeed, he suggests that the composition of the tale may have been inspired in particular by a battle fought in 1398 on the plain of Magh Tuireadh itself, which, as noted above, is located to the east of Lough Arrow on the border

${ }^{103}$ See above, 33-34, and also further discussion in Hayden, 'Three versified medical recipes', $120-21$.

${ }^{104}$ Walsh, 'An Irish medical family', 210 and 214.

${ }^{105}$ Hoyne, 'The assassination of Mag Rághnaill'; see above, n. 33.

${ }^{106}$ Mícheál Hoyne, 'The political context of Cath Muighe Tuireadh, the early modern Irish version of the Second Battle of Magh Tuireadh', Ériu 63 (2013), 91-116, at 113. The early modern Irish version of the narrative has been edited by Brian Ó Cuív, Cath Muige Tuired: the second battle of Magh Tuireadh (Dublin, 1945). 
of Counties Sligo and Roscommon - a mere $20 \mathrm{~km}$ north of Killaraght, the parish in which Connla Mac an Leagha was based while he copied part of his medical compendium. ${ }^{107}$

In light of this connection, it might therefore be argued that the scribe and practising physician Connla Mac an Leagha, or perhaps one of his hereditary predecessors in the profession, chose to include so many references to Irish mythological tradition in this compendium of medical recipes simply because they had a particular familiarity with various strands of the narrative relating to the mythical Battle of Magh Tuireadh — an event thought to have taken place in the same geographical region as that in which the Mac an Leagha medical practitioners were largely based, and one which so prominently featured figures of the Túatha Dé such as Dían Cécht, Míach, Airmed and the Dagda. Acquaintance with material of this nature could well have stemmed from the Mac an Leagha physicians' association with other literate professionals then in the employ of the Meic Dhiarmada, in particular the Uí Dhuibhgeannáin poet-historians located in nearby Cill Rónáin during the early fifteenth century.

When considered alongside other features of the compendium, such as its inclusion of several charms and metrical recipes, the presence of these mythological attributions also raises compelling questions regarding the relationship between vernacular Irish medical texts and other contemporary genres of literary and technical writing. Taken as a whole, Connla Mac an Leagha's compendium is clearly situated within the broader genre of empirically oriented receptaria that are widely attested in both Latin and other vernacular languages, and which aimed at practical convenience and utility more so than the kind of scholastic inquiry typical of many late medieval medical commentaries. In this regard, the compendium might be seen to serve a similar function to that associated with many of the extant Irish law-tracts, the majority of which were clearly conceived as legal notebooks prepared by jurists for their studies rather than as records of proceedings. ${ }^{108}$ Such 'legal manuals' preserve a similar mixture of prose and verse material as is found in the medical text examined here, while their authors also frequently make use of mythical precedents to authenticate either the contents of entire texts (as is the case with Bretha Déin Chécht and the other 'craft-judgements' associated with the Senchas Már) or individual elements within them, for example figures from heroic sagas whose actions are cited as 'leading cases' to explain particular legal situations or innovations. ${ }^{109}$ In this sense, it may yet prove possible to identify similar kinds of connections between some of the extant Irish medical texts and other genres of

\footnotetext{
107 See above, $27-28$.

${ }^{108}$ On this, see for example the remarks by Breatnach, 'The early Irish law text Senchas Már', 10-11. ${ }^{109}$ For discussion of the latter, see my remarks in Hayden, 'Three versified medical recipes', as well as D. A. Binchy, 'Echtra Fergusa Maic Léti', in Myles Dillon (ed.), Irish sagas (Dublin, 1959), 38-50, at 38-40, and the more recent inventory of leading cases by Fangzhe Qiu, 'Narratives in early Irish law: a typological study', in Anders Ahlqvist and Pamela O'Neill (eds), Medieval Irish law: text and context, Sydney Series in Celtic Studies 12 (Sydney, 2013), 111-41.
} 
Irish technical prose as have been noted by Owen in relation to the Welsh medical and legal tracts. ${ }^{110}$

There is, of course, clearly much editorial and critical work yet to be done on the medical compendium discussed here before it will be possible to draw any truly satisfactory conclusions concerning the nature of the sources drawn upon by the compiler, the date of the work as a whole or of individual parts within it, and the text's place within the wider realm of medieval Irish - and indeed Europeanmedical learning. This preliminary survey of authoritative attributions has merely sought to set the ball rolling in this direction by bringing some of this unpublished material to light, and by offering some observations concerning its wider literary, historical and cultural context. What emerges clearly from this analysis is that the compendium in question presents a rather more nuanced picture of the surviving evidence for medical learning in medieval Ireland than that once painted by figures such as O'Grady, Binchy and Shaw. Jason Harris has recently observed that

the real significance of the Irish and Scottish vernacular medical manuscripts is that they demonstrate that Gaelic physicians were entirely in step with developments elsewhere in northern Europe, not within the scholastic, university based discipline of medicine, but in the broader process of 'vernacularization' which has come to be seen as distinctive of medical and scientific history in this period. ${ }^{111}$

Several aspects of the text examined here readily illustrate this complex and continually evolving tradition of preserving, compiling and adapting medical material through the medium of the Irish language in the premodern period, and lend support to the more recently emerging picture of a localised and practically oriented-but nonetheless still outward-looking - medical community whose vernacular writings would, in more than one respect, bear further comparison to those of its Insular and Continental neighbours.

When examined from the perspective of its authoritative attributions in particular, Connla Mac an Leagha's medical compendium clearly demonstrates that at least some written evidence has survived from medieval Ireland to show that the scholars and scribes responsible for preserving medical material were not merely slavish transmitters of Classical and Renaissance medical doctrine, enamoured of the discursive argumentation and philosophical dogmatism so often associated with the scholastic methods of the late medieval universities. They were, to the contrary, both attuned to the necessities of everyday medical practice and also very much alive to the wider resonances of medieval Irish literary tradition. ${ }^{112}$

\footnotetext{
${ }^{110}$ See above, 26.

${ }^{111}$ Harris, 'Latin learning and Irish physicians', 19.

${ }^{112}$ I am grateful to Liam Breatnach and Uáitéar Mac Gearailt for reading drafts of this article and suggesting many important improvements. All remaining errors or shortcomings are my responsibility alone.
} 